action on them. Marriage is inadvisable unless the condition is fully explained to the contemplated bride and a responsible relative.

\section{Effect of Amphetamine}

Q.-Amphetamine taken before meals seems to reduce the appetite. This might be of benefit in obesity, but would it predispose to gastric ulcer? Is the initial stimulation of the brain followed by depression? Any other pharmacological pcints would be welcomed.

A.-Amphetamine has been shown to reduce the appetite of rats. It affects the normal human stomach by first stimulating it so that emptying is hastened, and later inhibiting its action so that emptying is delayed. There is increased pyloric tone, though in spastic states there "may be the opposite effect-a relaxation of spasm. Gastric acidity is not appreciably affected by amphetamine. The stimulation of the brain produced by the drug leads to prolonged wakefulness at a time when the subject would normally be recruiting his strength by sleep thus reserves are exhausted and collapse is common. While some can take the drug for long periods without collapse occurring. others are adversely affected much earlier. Patients receiving amphetamine may complain of flatulence, anorexia, nausea, abdominal pains, and an increase or a decrease in bowel movements.

\section{Phenylmercuric Nitrate and Chloride}

Q. - I would like information about phenylmercuric nitrate and phenylmercuric chloride. What are their possible therapeutic uses?

A.-Phenylmercuric nitrate and phenylmercuric chloride are powerful fungicides and germicides, and when taken by mouth they exert a strong bacteriostatic and bactericidal effect in the blood, the cerebrospinal fluid, the bile, the urine, and the faeces. They have a low toxicity; for rabbits the minimum lethal dose of the nitrate is $0.01 \mathrm{~g}$. per kilo when given intravenously, and $0.03 \mathrm{~g}$. per kilo by mouth. When $250 \mathrm{ml}$. of 1 in 1,250 solution $(0.2 \mathrm{~g}$.) was taken orally by a human subject the only effect was a rise of pulse rate by 20 , though it caused a feeling of astringency in the mucous membrane of the mouth. These substances have no toxicity when applied to the skin, on which phenylmercuric nitrate is used in a strength of 1 in 3.000 . This substance is stated to be 78 times as potent against Gram-positive cocci as mercuric chloride. It is useful in ringworm and epidermophytosis (Levine, J. Amer. med. Ass., $1933,2,2108)$.

\section{Insect Repellents}

Q.-Can you recommend any new insect repellents for topical application for a patient residing in Calcutta who is particularly susceptible to insect bites and stings?

A.-Dimethyl or dibutyl phthalate rubbed on the skin gives satisfactory protection for several hours against most insect bites. These substances may cause smarting on abraded skin or in the eyes but are otherwise innocuous. They are solvents of many synthetic plastics and consequently contact with plastic watch-glasses, spectacle frames, etc., should be avoided. They may be used alone or incorporated into lotions or creams. They are not repellent but are lethal to mites, and rubbed into clothing are a most valuable protection against scrub typhus.

\section{INCOME TAX}

All inquiries will receive an authoritative reply but only a selection can be published.

\section{Assistantship : Expenses}

T. started as an assistant in general practice on Jan. 1, 1947; he asks what are the usual expenses which can be claimed.

** A salary as an assistant is assessable under Schedule E, and the statutory rule is that only those expenses which are incurred "wholly, exclusively and necessarily in the performance of the duties of the office" can be deducted. The main allowable expense is the cost of maintaining and running a car. $T$. can claim an initial allowance $(20 \%$ of $£ 295=£ 59)$ and wear-and-tear allowance $(t$ of $25 \%$ of $£ 295=£ 37$ ) as deductions from his earnings for the quarter from Jan. 1. Any other expenses which he is required by the terms of his engagement to bear can also be deducted-i.e., cost of professional use of telephone. He should get in touch with the local tax office and obtain an adjustment of his present coding.

\section{Letters and Notes}

\section{Sir William Macewen}

Mr. J., Menzies Campbell (Glasgow) writes: I recently read, with considerable pleasure and profit, Dr. Harley Williams's book, $c$ Doctors Differ. Although no one can controvert the austere and autocratic manner of Sir William Macewen, nevertheless I feel that another aspect of his nature should not pass unnoticed. The following incident occurred in the year of Sir William's presidency of the British Medical Association. A friend of mine (an eminent dentist in New York) was spending a golfing holiday at Turnberry. Unfortunately an abrasion in his hand became septic. He journeyed at once to Glasgow and telephoned that afternoon asking me to arrange an appointment for him with the best surgeon. I straightway telephoned Sir William Macewen, who personally answered the call. I explained the circumstances, and no one could have been more sympathetic and co-operative. He mentioned that he was at the moment overwhelmed with business relating to a B.M.A. Council meeting which he was to attend in London next day and for which he was leaving within a few hours. He asked me to request my friend to take a taxicab at once to his house and he would see him. After leaving Sir William the American called to inform me of the great kindness which he had received. Sir William had personally incised the finger and dressed and bandaged the wound. $\mathrm{He}$ met the inquiry about a fee with the response, "There is no fee: "we ' were pleased to be of any service to you."

\section{Half Cost, Double Value}

Dr. Josiah Oldfield (London, W.1) writes: Medical men can be of great service at this particular juncture, when fuel is so scarce, by teaching in every house they visit that in order to obtain a hot bath in perfection the ordinary bath should be covered in so as to turn it into a miniature Turkish bath. All that is needed is either to put a small clothes-horse across the bath or even a frame of boards or battens, and to lay over this frame either an old blanket or rug or even a few sheets of brown paper. Space should be left at the head end to slip into the bath, and the half quantity of water will give a more perfect bath by using the hot steam which lies above the water in place of filling the bath up to the usual full capacity.

\section{Marriage Guidance}

Dr. Philip M. Bloom (London, W.1) writes: The discussion in the House of Lords last week following the Denning Report was most interesting and certainly a most important peak in our educational history. The proposals of the Government to appoint welfare officers and to give material aid to the various clinics dealing with the divorce problem are most encouraging to those of us who are interested. I feel, however, that too much emphasis has been laid on solving and trying to adjust unhappy marriages rather than preventing them. I desire to put in a strong claim for more premarital guidance and instruction. The marriage guidance and similar clinics deal, inter alia, with this latter subject, but the importance of it has not been sufficiently stressed. A few young couples are already seeking help and my experience is that they are eager for information. I have no doubt that with encouragement a great many more young people would seek guidance. Pre-marital education and instruction along comprehensive lines go a long way towards preventing the development of incompatibilities and unhappiness in marriage.

Co-opted Members on Negotiating Committee : Correction

Dr. D. H. Stuart BoYd writes: The letter from myself (April 5, p. 469) contains an error which I unfortunately overlooked before signing. The phrase "bestowed on the negotiation and election of the Negotiating Committee " should, of course, have been " bestowed on the nomination and election of the Negotiating Committee."

\section{Correction}

A typist's slip caused Dr. A. M. Nussey's name to be misspelt in our report of the meeting of the Section of Endocrinology of the Royal Society of Medicine in the Journal of April 12 at p. 501.

All communications with regard to editorial business should be addressed to THE EDITOR, BRITISH MEDICAL JOURNAL. B.M.A. HOUSE. TAVISTOCK SQUARE, LONDON, W.C.1. TELEPHONE: EUSTON 2111. TELEGRAMS: Aitiology, Westcent, London. ORIGINAL ARTICLES AND LETTERS forwarded for offered to the British Medical Journal alone unless the contrary be stated.

Authors desiring REPRINTS should communicate with the Publishing Munager, B.M.A. House. Tavistock Square. W.C.1, on receipt of proofs.

ADVERTISEMENTS should be addressed to the Advertisement Manage B.M Huuse Toust B.M.A. House, Tavistock Square, London, W.C.1 hours TEMBER ' SUPSCRIPTIONS should be sent to the SECRETARY of AsER London.

B.M.A. SCOTtISH OfFICE: 7, Drumsheugh Gardens, Edinburgh.

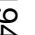
, 